\title{
Carcass Traits, Organ Proportion and Bio-Economic Cost Benefits Analysis of Broiler Chickens Fed Different Dietary Plant Protein Sources in Sorghum-Based Diet
}

\author{
Agida, C. A. ${ }^{1^{*}} \quad$ Onunkwo, D. N. ${ }^{1} \quad$ Ezenyilimba, B. N. ${ }^{2} \quad$ Afam-Ibezim, E. M. ${ }^{1} \quad$ Ukonu, A. B. ${ }^{1}$ \\ John, U. E. ${ }^{1}$ Adje, C. I. ${ }^{3}$ \\ 1. College of Animal Science and Animal Production, Michael Okpara University of Agriculture, Umudike, Abia State, \\ Nigeria \\ 2. Department of Animal Science, Faculty of Agriculture, Nnamdi Azikiwe University, Awka, Nigeria \\ 3. Department of Animal Science, Faculty of Agriculture, University of Port Harcourt, Nigeria
}

\section{ARTICLE INFO}

Article history

Received: 21 June 2021

Accepted: 20 July 2021

Published Online: 31 July 2021

\section{Keywords:}

Carcass characteristics

Organ proportions

Cashew nut cake

Groundnut cake

Soyabean

Sorghum

Broiler birds

\begin{abstract}
A 56-day study was carried out to evaluate the carcass characteristics and organ proportions of broiler chickens fed sorghum-based diets with varying plant protein. A total of 120 day-old broiler chickens from a reputable and disease free farm were used for this study. There were four treatments, each having thirty broiler birds replicated thrice with ten broiler birds per replicate using a Completely Randomized Design (CRD). The broiler birds were offered feed and water ad libitum. The growth parameters were taken on weekly basis. Carcass evaluation was carried out at the end of the trial. One bird per replicate was randomly selected, fasted over-night and slaughtered by severing the jugular vein. After scalding in warm water for about a minute, the feathers were manually plucked. Each bird was cut into parts for carcass evaluation. The relative weights of the cut parts were as a percentage of dressed weight. The internal organs, such as heart, kidney, gizzard/proventriculus were all weighed separately and recorded using electric micrometer ( $3000 \mathrm{~g}$ weighing gauge). The findings from this study showed that all the carcass parameters considered showed significant differences $(\mathrm{p}<0.05)$. Birds fed diet 3 gave the best live weight, slaughtered weight, defeathered weight, dressed weight and commensurate cut-parts. Soybean (whether cake or full-fat) demonstrate superiority over groundnut cake and cashew nut cake. Birds fed diet 3 gave the highest value of thigh, breast -cut, drumstick and wings, while birds fed diets 2, 1 and 4 gave less. The organ proportions of broiler chickens fed different dietary plant sources have all the parameters significantly difference $(p<0.05)$, except the lungs though without any definite pattern. Average weight gain and feed conversion ratio were better $(\mathrm{p}<0.05)$ among birds fed diet 2 , and 3 . Cost benefits analysis per kilogram in naira terms for birds fed different plant protein sources in a sorghum-based diets were significant $(\mathrm{p}<0.05)$ among treatment levels. Least cost per $\mathrm{kg}$ feed was obtained in diet $1(\mathrm{p}<0.05)$. Cost of weight gained was $(\mathrm{p}<0.05)$ low in $\mathrm{T} 1$. Cost of feed consumed was low for diet $\mathrm{T} 1$ and $\mathrm{T} 3$. Revenue, gross margin and cost benefit ratio estimated were found to high $(\mathrm{p}<0.05)$ among T2 and T3. Broiler chickens fed diet 3 gave the best parameters. The actual contributions of the experiment, is to alternatively replace corn with sorghum completely at least cost with optimum performance.
\end{abstract}

*Corresponding Author:

Agida, C. A.,

College of Animal Science and Animal Production, Michael Okpara University of Agriculture, Umudike, Abia State, Nigeria;

Email: agidachrisagboje@gmail.com; agboje.agida@mouau.edu.ng 


\section{Introduction}

The rising cost of poultry feeds have continued to be a major problem in developing countries as feed cost is about 65 to $70 \%$ of the total cost of production (Onunkwo et al., 2019) and poultry industry has suffered more than any other livestock industry as a result of this. Cereal grains constitute the major source of energy in poultry feeds in the tropics (Oluyemi and Robert 2000). Cereal grains, especially maize form the bulk of energy in poultry feeds are in short supply as a result of industrial and human competition. This has resulted in competition between human and animals for available feed resources, and hence high cost of animal production. Pressure on maize has been on the increase worldwide (Onunkwo et al., 2018) and this trend requires serious diversification of energy feed stuff for poultry. Sorghum (Sorghumi bicolor) is a crop which is similar in composition to maize and can be successfully cultivated in the semi-arid regions of Asia and Africa and it is cheaper and more readily available than maize (Douglas et al., 1993). A comparative increment in demand for essential ingredients such as maize, soybeans meal, sorghum grains, groundnut cake and fish meal by man and animals has further exacerbated the high cost of compounded conventional feeds for poultry in $\mathrm{Ni}$ geria and the world over (Jaji, et al., 2011).

The sourcing least cost alternative feed stuff, which are mostly waste not consume by humans and are readily available and affordable as against expensive conventional ones in the animal agriculture has been suggested (Agida, et al., 2019a). This will be a higher percentage alleviate global food crisis and ameliorate food security (Anigbogu et al., 2020; Agida, et al., 2019b). Demand for maize grains between man, industries and livestocks has been on the increase (Agida, et al., 2019b; Olomu, 2011). These have further been exacerbated during the 2020 Covid-19 pandemic year, where agricultural activities were at an almost completely lock down.

Hence it is necessary to evaluate of the carcass characteristics of birds fed different plant protein sources (Groundnut cake, Cashew nut cake, Soyabean meal and Soyabean cake) in a Sorghum-based diet.

\section{Materials and Method}

This study was carried out in the Poultry unit of the Teaching and Research farm, Michael Okpara university of Agriculture, Umudike, Abia State. Umudike is located on latitude $05^{\circ} 21^{\prime} \mathrm{N}$ and longitude $07^{\circ} 33^{\prime} \mathrm{E}$, with an elevation of about $112 \mathrm{~m}$ above sea level. The location has an annual rainfall of $177-2,000 \mathrm{~mm}$ per annum, (April to October) and a short period of dry season (November to March) with a relative humidity of about $50-90 \%$ and monthly temperature range of $17^{\circ} \mathrm{C}-36^{\circ} \mathrm{C}$ (NRCRI, 2019).

A total of 120day-old Ross strained unsexed chicks were weighed and randomly allotted to four equal treatment groups (T1, T2, T3 and T4) each having 30 chicks. Each treatment was replicated three times of 10 chicks per replicate. The birds were offered feed and water ad libitum in a deep litter pen. Carcass evaluation was carried out at the end of the feeding trial. One bird per replicate was randomly selected, fasted overnight and slaughtered by severing the jugular vein. After scalding in warm water for about a minute, the feathers were manually plucked. Each bird was cut into parts for carcass evaluation according to (Ojewola et al., 2001). The relative weights of the cut parts are as a percentage of dressed weight. The internal organs, such as heart, kidney, gizzard/proventriculus were all weighed separately and recorded using electric micrometer $3000 \mathrm{~g}$ weighing gauge.

Performance cost benefits analysis was computed by assessment of each of the feed cost per ingredient purchased in Naira value per $\mathrm{kg}$. Cost of $\mathrm{kg}$ feed equal total cost of $1 \mathrm{~kg}$ of feed stuff. Cost of a $\mathrm{kg}$ weight gain equal feed conversion ratio multiply total feed consumed. Cost of production equal cost per $\mathrm{kg}$ weight gain multiply mean weight gain. Revenue estimate is equal price of $1 \mathrm{~kg}$ of table sized broiler chicken multiply mean weight gain. Gross margin estimate is equal revenue estimated minus cost of production estimated. Average daily feed intake in grams is total feed intake divide by the number of birds per total number of experimental days. Average daily weight gain in grams is the aggregate sum of the weight gain in a treatment replicate divide by the total numbers of experimental birds per days of experimental trials.

All data generated were subjected to Analysis of Variance (ANOVA) and treatment means that were significantly different were separated using Duncan's Multiple Range Test (Duncan, 1955).

\section{Results and Discussion}

The results of the Carcass characteristics of birds fed different plant protein sources in a Sorghum-based diet are presented in Table 2. The result showed that all the carcass parameters considered showed a significant difference $(\mathrm{p}<0.05)$. The poorer values exhibited by birds fed diets 4 and 1 could be attributed to the different abilities of the test diets to support tissue deposition. Nonetheless, birds fed diet 3 gave the best live weight, slaughtered weight, defeathered weight, dressed weight and commensurate cut-parts. This is closely followed by the birds fed diet 2 . The implication of this is that soybean (whether cake or 
full-fat) demonstrate superiority over groundnut cake and cashew nut cake. The differences obtained in the cut-parts values may be attributed to similar reasons considering the highest (significant values) of thigh, wing, breast-cut and back-cut for birds fed diet 3 when compared to diets 2, 1 and 4; diet 3 is simply a diet of choice. The result further showed that cut-parts (drumstick, thigh and wing) bore a relationship with carcass weight-supporting the view of (Ojewola and longe, 2000) that weights, volumes and dimensions of broiler parts were directly related to the carcass weight. This is also in agreement with the findings of (Ojewola and Ewa, 2005), who confirmed that heavier birds produced a greater eviscerated yield. This is a further confirmation of the fact that plump appearance in broiler was associated with high percentage of edible meat. Birds fed diet 3 gave the highest value of thigh, breast-cut, drumstick and wings. However, birds fed diet 2, 1 and 4 gave less. This shows the ability of test diet (T3) to support tissue deposition more than the others. The back-cut of birds fed diet 3 also gave the highest value when compared to others.

The results of organ proportions of broiler chickens fed

Table 1. Gross Percent composition of experimental diet

\begin{tabular}{|c|c|c|c|c|}
\hline Ingredients & $\mathrm{T}_{1}$ & $\mathrm{~T}_{2}$ & $\mathrm{~T}_{3}$ & $\mathrm{~T}_{4}$ \\
\hline Sorghum & 63.30 & 63.30 & 63.30 & 63.30 \\
\hline Groundnut cake & 30 & - & - & - \\
\hline Soyabean meal (full fat) & - & 30 & - & - \\
\hline Soyabean cake & - & - & 30 & - \\
\hline Cashew nut cake & - & - & - & 30 \\
\hline Fish meal (local) & 3.00 & 3.00 & 3.00 & 3.00 \\
\hline Bone meal & 3.00 & 3.00 & 3.00 & 3.00 \\
\hline Salt & 0.25 & 0.25 & 0.25 & 0.25 \\
\hline Vitamin Premix & 0.25 & 0.25 & 0.25 & 0.25 \\
\hline Methionine & 0.10 & 0.10 & 0.10 & 0.10 \\
\hline Lysine & 0.10 & 0.10 & 0.10 & 0.10 \\
\hline Total & 100.00 & 100.00 & 100.00 & 100.00 \\
\hline \multicolumn{5}{|l|}{ Calculated analysis } \\
\hline Percent crude protein & 22.26 & 21.36 & 21.36 & 22.26 \\
\hline ME (Kcal/kg) & 3030 & 3168 & 3048 & 3198 \\
\hline Calorie protein ratio & 1.136 & 1.148 & 1.143 & 1.144 \\
\hline
\end{tabular}

*premix supply per kg broiler diet: Vitamin A 1500IU, Vitamin $\mathrm{D}_{3}$ 13000IU, Thiamin 2mg, Riboflavin 6mg, Pyridoxine 4mg, Niacin 40mg, Cobalamine 0.05g, Biotin 0.08mg, Chlorine chloride 0.05g, Manganese 0.096g, Zinc 0.06g, Iron 0.024g, Copper 40mg, Iodine $0.014 \mathrm{~g}$, Selenium $0.24 \mathrm{mg}$, Cobalt $0.024 \mathrm{mg}$ and antioxidant $0.125 \mathrm{~g}$.

Table 2. Carcass characteristics of birds fed different plant protein sources in a Sorghum-based diets

\begin{tabular}{cccccc}
\hline Parameters & $\mathrm{T}_{1}$ & $\mathrm{~T}_{2}$ & $\mathrm{~T}_{3}$ & $\mathrm{~T}_{4}$ & SEM \\
\hline Live weight & $1000.00^{\mathrm{b}}$ & $1892.67^{\mathrm{a}}$ & $2016.67^{\mathrm{a}}$ & $900.00^{\mathrm{b}}$ & 153.67 \\
Slaughtered weight & $955.00^{\mathrm{bc}}$ & $1866.67^{\mathrm{a}}$ & $1983.33^{\mathrm{ab}}$ & $850.00^{\mathrm{c}}$ & 147.29 \\
Defeathered weight & $908.33^{\mathrm{b}}$ & $1750.00^{\mathrm{a}}$ & $1818.33^{\mathrm{a}}$ & $778.33^{\mathrm{b}}$ & 144.69 \\
Dressed weight & $751.67^{\mathrm{b}}$ & $1610.00^{\mathrm{a}}$ & $1663.33^{\mathrm{a}}$ & $681.67^{\mathrm{b}}$ & 140.69 \\
Shank & $56.00^{\mathrm{b}}$ & 73.67 & $87.67^{\mathrm{a}}$ & $42.33^{\mathrm{b}}$ & 5.52 \\
Thigh & $195.00^{\mathrm{b}}$ & $228.67^{\mathrm{a}}$ & $236.33^{\mathrm{a}}$ & $115.33^{\mathrm{c}}$ & 39.46 \\
Breast-cut & $212.33^{\mathrm{c}}$ & $354.67^{\mathrm{b}}$ & $478.67^{\mathrm{a}}$ & $152.33^{\mathrm{c}}$ & 39.46 \\
Back-cut & $139.00^{\mathrm{c}}$ & $311.33^{\mathrm{a}}$ & $281.33^{\mathrm{ab}}$ & $214.33^{\mathrm{b}}$ & 21.87 \\
Drumstick & $102.67^{\mathrm{b}}$ & $179.00^{\mathrm{a}}$ & $193.33^{\mathrm{a}}$ & $77.67^{\mathrm{b}}$ & $74.67^{\mathrm{b}}$ \\
Wings & $88.00^{\mathrm{b}}$ & $170.67^{\mathrm{a}}$ & $181.33^{\mathrm{a}}$ & $32.00^{\mathrm{c}}$ & 15.27 \\
Head & $41.67^{\mathrm{b}}$ & $50.33^{\mathrm{a}}$ & $55.67^{\mathrm{a}}$ & $87.67^{\mathrm{c}}$ & 14.73 \\
Neck & $66.33^{\mathrm{ab}}$ & $82.33^{\mathrm{a}}$ & $89.00^{\mathrm{a}}$ & 2.85 \\
\hline
\end{tabular}

$a, b, c, d$ values with different superscripts on same row are significantly different $(p<0.05)$ 
different dietary plant protein sources in sorghum-based diet are shown in Table 3. All the parameters showed significant differences $(p<0.05)$, except the lungs though without any definite pattern. The lowest value of kidney weight in birds fed diet 4 is understandable knowing that cashew nut meal has known to be high in toxic substances like some other oil seed (Odunsi, 1999). Thus, the kidney-based enzymes may exhibit reduced activities. Average feed intake was not significant $(\mathrm{P}>0.05)$ across treatments in Table 4. It shows that energy and protein requirements were made as obtained from the formulated diets. Average daily weight gain and feed conversion ration were found to be better $(\mathrm{P}<0.05)$ for birds fed diets $\mathrm{T} 3$ and T2 respectively, this is attributed to efficiency of utilization of its dietary protein, better amino acids profile and a balance dietary composition as regards protein-energy ratio and other unexplainable factors, although particle size on sorghum-based diets fed broiler chickens did not affect the performance of the birds as observed by (Fernandes et al., 2013).

Cost benefits analysis as presented in Table 4, where significant $(\mathrm{P}<0.05)$ across treatment levels. Birds fed diet T1 showed significantly $(\mathrm{P}<0.05)$ lower cost/kilogram of feed. The decline in cost, was as a result of cheaper cost of 1 kilogram groundnut cake to other plant protein source used in the experiment. Cost of a kilogram weight gained was found to be cheaper $(\mathrm{P}<0.05)$ among birds fed diet 3 , and a higher $(\mathrm{P}<0.05)$ cost was obtained for birds fed diet 4. The high cost was due to high cost of cashew nut cake which is relatively very expensive as the demand for cashew nut is very high. Contrary to previous findings by (Jaji et al., 2011; Taiwo et al., 2015), cashew reject meal (CRM) fed to broilers and layers chicken, showed low economic cost. As maize and soyabean are the major sources of energy and protein in the poultry and livestock industry, ways of having $100 \%$ replacement for corn and soyabean as energy and protein sources with alternative feed source are been sorted for, which form the basis for its comparative studies. As the quest for a cheaper alternative feed sources are high, the cost of broiler production per kilogram of weight produced differ significantly $(\mathrm{P}<0.05)$ across treatments. A higher cost was obtained in birds fed

Table 3. Organ proportions of broiler chicken feed different dietary plant protein sources in sorghum-based diets

\begin{tabular}{cccccc}
\hline Response criteria & $\mathrm{T}_{1}$ & $\mathrm{~T}_{2}$ & $\mathrm{~T}_{3}$ & $\mathrm{~T}_{4}$ & SEM \\
\hline Lungs & 14.00 & 15.00 & 15.00 & 15.67 & 0.66 \\
Heart & $8.73^{\mathrm{b}}$ & $9.33^{\mathrm{b}}$ & $11.00^{\mathrm{a}}$ & $8.50^{\mathrm{b}}$ & 0.33 \\
Liver & $22.00^{\mathrm{c}}$ & $37.00^{\mathrm{a}}$ & $47.00^{\mathrm{a}}$ & $18.00^{\mathrm{c}}$ & 3.56 \\
Gizzard & $23.00^{\mathrm{c}}$ & $34.67^{\mathrm{b}}$ & $40.00^{\mathrm{a}}$ & $19.00^{\mathrm{d}}$ & 2.59 \\
Crop & $23.00^{\mathrm{c}}$ & $11.00^{\mathrm{ab}}$ & $11.33^{\mathrm{a}}$ & $7.00 \mathrm{a}^{\mathrm{b}}$ & 0.91 \\
Intestine & $63.67^{\mathrm{b}}$ & $117.33^{\mathrm{a}}$ & $108.67^{\mathrm{a}}$ & $56.33^{\mathrm{ab}}$ & 8.50 \\
Proventriculus & $4.00^{\mathrm{b}}$ & $7.00^{\mathrm{a}}$ & $7.67^{\mathrm{a}}$ & $5.33^{\mathrm{ab}}$ & 0.56 \\
Spleen & $0.33^{\mathrm{b}}$ & $2.33^{\mathrm{a}}$ & $1.67^{\mathrm{a}}$ & $0.00^{\mathrm{b}}$ & 0.32 \\
Kidney & $5.33^{\mathrm{b}}$ & $11.33^{\mathrm{a}}$ & $14.00^{\mathrm{a}}$ & $5.67^{\mathrm{b}}$ & 1.22 \\
\hline
\end{tabular}

a,b,c,d values with different superscripts on same row are significantly different $(\mathrm{p}<0.05)$

Table 4. Performance/cost benefits analysis of broiler chicken feed different dietary plant protein sources in sorghum-based diets

\begin{tabular}{|c|c|c|c|c|c|}
\hline Parameters & $\mathrm{T}_{1}$ & $\mathrm{~T}_{2}$ & $\mathrm{~T}_{3}$ & $\mathrm{~T}_{4}$ & SEM \\
\hline Average feed weight gain & 85.04 & 82.19 & 83.32 & 83.05 & 0.60 \\
\hline Average daily weight gain & $17.86^{\mathrm{b}}$ & $33.80^{\mathrm{a}}$ & $36.01^{\mathrm{a}}$ & $16.07^{\mathrm{c}}$ & 5.21 \\
\hline Feed conversion ratio & $4.80^{\mathrm{b}}$ & $2.43^{\mathrm{a}}$ & $2.31^{\mathrm{a}}$ & $5.17^{\mathrm{b}}$ & 0.76 \\
\hline Cost/kg of feed ( & $121.07^{\mathrm{a}}$ & $186.17^{\mathrm{b}}$ & $134.57^{\mathrm{c}}$ & $319.07^{\mathrm{d}}$ & 4.63 \\
\hline Cost of a kg weight gain ( & $0.58^{\mathrm{c}}$ & $0.45^{\mathrm{b}}$ & $0.31^{\mathrm{a}}$ & $1.65^{\mathrm{d}}$ & 0.305 \\
\hline Cost of production/kg ( & $10.38^{\mathrm{b}}$ & $6.29^{\mathrm{a}}$ & $11.19^{\mathrm{b}}$ & $26.51^{d}$ & 8.875 \\
\hline Cost/kg feed consumed ( & $10.38^{\mathrm{a}}$ & $15.29^{\mathrm{c}}$ & $11.19^{\mathrm{a}}$ & $26.51^{d}$ & 3.715 \\
\hline Gross margin ( & $4.80^{\mathrm{c}}$ & $13.44^{\mathrm{b}}$ & $19.41^{\mathrm{a}}$ & $-12.85^{\mathrm{d}}$ & 7.02 \\
\hline Cost benefit ratio/kg ( & $1.46^{\mathrm{c}}$ & $1.88^{\mathrm{b}}$ & $2.74^{\mathrm{a}}$ & $0.52^{\mathrm{d}}$ & 0.46 \\
\hline
\end{tabular}

$\mathrm{a}, \mathrm{b}, \mathrm{c}, \mathrm{d}$ values with different superscripts on same row are significantly different $(\mathrm{p}<0.05)$, The revenue estimates was computed at ( $850 / \mathrm{kg}$ table sized broiler chicken. 
diet 4 when compare with other treatments.

Cost of feed consumed per kilogram was better $(\mathrm{P}<0.05)$ among birds fed diets $\mathrm{T} 1$ and $\mathrm{T} 2$ respectively. Diet $\mathrm{T} 4$ was found to be higher $(\mathrm{P}<0.05)$ and relatively very expensive. This was relative to the cost of a kilogram cashew nut and poor dietary utilization as a result of poor efficiency of feed conversion. Revenue in naira per kilogram had higher $(\mathrm{P}<0.05)$ amount obtained when birds were fed diet $\mathrm{T} 3$ and $\mathrm{T} 2$, with lower $(\mathrm{P}<0.05)$ revenue estimated for birds fed diets $\mathrm{T} 1$ and $\mathrm{T} 4$. It is common among birds that the feed conversion efficiency clearly defines their overall performance and has a direct reflection on their cost benefits in relation to weight gain for every gram of feed consumed.

Gross margin as indication of estimated profit was found to be highest $(\mathrm{P}<0.05)$ among birds fed diet $\mathrm{T} 3$. The gross margin showed $(\mathrm{P}<0.05)$ negative amount in naira for birds on T4. It indicates loss of investment for birds fed experimental diets T4. This further, disclose a high cost of test plant protein source that reflected a comparative demand between man and animal creating a direct cost effect on using such plant protein source as replacement for soyabean. Taiwo et al., (2015) and Jaji et al., (2006) ascertain the use of cashew reject meal (CRM) as a better alternative for economic gain in feeding poultry than the accepted kernel, due the high demand between man than an animal on the side of accepted kernel. Freitas et al., (2006) reported increasing economic efficiency ratio and a reduction in cost when cashew nut meal (CNM) was fed to broilers at $25 \%$ inclusion levels. Gomes et al., (2020) on feeding growing rabbits, also obtained low cost and economic gained in feeding 5\% cashew nut meal replacement levels on soybean base diets. Cost benefit ration showed $(\mathrm{P}<0.05)$ quick return and attractive investment figure for birds fed diet $\mathrm{T} 3$ followed by $\mathrm{T} 2$, with a discouraging investment figure for $\mathrm{T} 4$. The values buttress the facts that cost benefit ratio served as an indicator for investment finders. It shows that, to every 1 digit of money spent on a commodity, a certain value to profit gain or expected must be obtained, which must not be less or equal to 1 .

\section{Conclusions}

Broiler chickens fed diet 3 which is the diet containing $30 \%$ soybean meal gave the best performance both in carcass quality, organ proportion and bio-economics cost benefit analysis, while diet 4 containing 30\% cashew nut meal has poor performance. High cost of cashew kernel in Nigeria discourage its uses as alternative plant protein source, hence its high demand by man and scarcity made it very expensive.

\section{References}

[1] Agida, C. A., Ukoha, O. A., Ukachukwu, S. N. and Amaefule, K. U. (2019). Proximate, mineral analysis and growth performance of broiler chickens fed diets containing palm oil mill effluent. Nigerian Agricultural Journal, 50(2): pp 81-86.

[2] Agida, C. A., W., Nathaniel, J. Ukoha, O. A. and Ukachukwu, S. N. (2019). Haematological and serological indices of broiler finisher chickens fed diets with palm oil mill effluent as replacement for maize. Nigerian Agricultural Journal, 50(2): pp 38-44.

[3] Douglas, J.H., Sullivan, T.W., Gonalez, N.J and Beck, M.M. (1993). Differential age response of turkeys to protein and sorghum tannin levels. Poultry Science, 72:1944-1951.

[4] Duncan, D.B. (1955). Multiple range and multiple F tests. Biometrics, 11:1-42.

[5] Freitas E.R, Fuentes M.F.F, Santos Júnior A.S, Guerreiro M.E.F, Espíndola G.B. (2006). Farelo da castanha de caju em rações para frangos de corte. Pesquisa Agropecuária Brasileira, 41(6):1001-1006.

[6] Gomes, T. R., Freitas, E. R., Watanabe, P. H., Sousa, A. R and Ferreira, A. C. S. (2020). Cashew nut meal (Anacardium occidentale L.) in the feeding of growing rabbits. Zootecnica. Ciênc. anim. bras. 21. https://doi.org/10.1590/1809-6891v21e-61927.

[7] International Journal of Poultry Science 4(10) 765 771.

[8] Jaji, M. F. O., Onigemo, M. A. and Adeyemo, M. A. (2011). Economics of substituting cashew nut waste for maize in the growth performance of broiler chicken. Proceedings of International Journal of Agricultural Economics and Extension, Vol. 5

[9] NRCRI (2019). Agro-meterological unit, National Root Crops Research Institute, Umudike, Umuahia, Nigeria.

[10] Odunsi A.A (1999). Feeding values of cashew kernel meal in the diet of the finishing broiler chickens. $\mathrm{Ar}$ chivos de. Zootechnia 51. 423 - 429.

[11] Ojewola G.S and Longe O.G (2000) Evaluation of the productive and economic efficiencies of cowpea hall and maize offal inclusion in layers ration. Nigerian Journal of Animal Production 27 (1) 35 - 39.

[12] Ojewola G.S and Ewa U. E (2005) Response of growing Broiler to varying dietary plant protein. International Journal of Poultry Science 4(10) 765 771.

[13] Ojewola, G.S. Abasiekong S.F. and Nwachukwu, C. S. (2001). Methionine supplementation in diets: productive efficiency, carcass characteristics and 
economics of growing indigenous turkey. Tropical Journal of Animal Science; 4:161 - 170.

[14] Oluyemi, J.A and Roberts F.A. (2000). Poultry production in warm wet climates Macmillan Publishers. London. Pp 132.

[15] Onunkwo, D. N, Amaduruonye, W and Daniel-Igwe, G (2018). Assessment of abattoir wastes (bovine blood and rumen content) on carcass characteristics, internal organs and organoleptic properties of broiler birds. Nigerian Agricultural Journal. 49(1): 201-209.
[16] Onunkwo, D. N., Anyaegbu, B. C., Ezike, J. C and Daniel-Igwe, G (2019). Dietary substitution of soya bean meal with processed African yam bean meal as protein source in the diets of finisher broilers. Nigerian Journal of Animal Production, 46(2):118-127.

[17] Taiwo, O. A., Akinyinka, O. A and Taye, O. A. (2015). Cashew reject meal in diets of laying chickens: nutritional and economic suitability. Journal of Animal Science and Technology, 57:17. DOI: 10.1186/s40781.015.0051-7. 